\title{
Implicit Anthropologies in Pre-philosophical Śaivism with Particular Reference to the Netra-tantra
}

\author{
Gavin Flood ${ }^{1,2}$ (D)
}

Published online: 16 July 2020

(C) The Author(s) 2020

\begin{abstract}
While there are overt philosophies of the person in both dualistic and non-dualistic Śaivism that developed their doctrines explicitly in relation to each other and to non-Śaiva traditions, especially Buddhism, many Śaiva texts exemplify what might be called a pre-philosophical discourse. Such works contain philosophical ideas but do not present systematic arguments (that is the job of later commentators) and are often regarded as divine revelation (namely the tantras but other genres of literature might also be included such as paddhatis). It is this layer of the articulation of concepts linked to practices that the paper exposes, which the arguments of the later philosophers reflect upon and from which they develop. The claim here is that through an analysis of pre-philosophical literature, texts such as the Netra-tantra, we can build a picture of the conceptual universe of the early medieval period that forms the basis for the development of thinking by the later philosophers. One way of doing this is through the micro-study of particular textual passages and from that to build a larger picture of pre-philosophical discourse.
\end{abstract}

Keywords Śaivism $\cdot$ Netra tantra $\cdot$ Pre-philosophical discourse $\cdot$ Self

\section{Abbreviations}

ISG İsānaśivagurudevapaddhati

K Netra-tantra as published in the KSTS edition

KSTS Kashmir series of texts and studies

$\mathrm{Na} \quad$ Amrteśatantra, NAK MS 1-285, NGMPP Reel No. B 25/5

$\mathrm{Nb} \quad$ Amrteśatantra, NAK 5-4866, NGMPP Reel No. A 171/12

NAK National archives of Nepal, Kathmandu

Gavin Flood

gavin.flood@theology.ox.ac.uk

1 Campion Hall, Oxford University, Oxford, UK

2 Oxford Centre for Hindu Studies, Oxford, UK 
NGMPP Nepal-German manuscript preservation project

NT Netratantra

NTU Netroddyota

\section{Introduction}

While there are overt philosophies of the person in both dualistic and non-dualistic Śaivism that developed their doctrines explicitly in relation to each other and to non-Śaiva traditions, especially Buddhism, many Śaiva texts exemplify what might be called a pre-philosophical discourse. Such works contain philosophical concepts but do not present systematic arguments (that is the job of commentators) and are often regarded as divine revelation (namely, the tantras but other genres of literature might also be included such as paddhatis). It is this layer of the articulation of concepts linked to practices that I hope to expose, which the arguments of the later philosophers reflect upon and from which they develop. My claim here is that through an analysis of pre-philosophical literature we can build up a picture of the conceptual universe of the early medieval period concerning the person, that forms the basis for the development of thinking by the later philosophers about metaphysical problems concerning the self. One way of doing this is through the micro-study of particular textual passages and from that to build a larger picture of pre-philosophical discourse. Text is an index of wider social attitudes and while this material does not give us direct accounts of how people lived, it does provide evidence for how people thought about their lives, their hopes, fears, and their aspirations. But before beginning such an enterprise, I need to clarify (a) what I mean by 'pre-philosophical discourse' and (b) what I mean by 'implicit anthropologies,' in order to develop a line of argument that the Netra-tantra exhibits distinct understandings of the human person, along with (c) the methodological principles by which such a claim might be established.

\section{(a) Pre-philosophical Discourse}

Philosophy is not enacted outside of cultures and there is a background, the possibility of thinking, that diverse philosophies share. Even confrontational philosophical positions are mutually comprehensible because of this background. As François Jullien observes in the Chinese situation, 'the most diverse and even opposing points of view are able to stake out their distinctive positions with mutual comprehension because of this shared background.' 1

This is also the case with Indic traditions: that the Śaiva Siddhānta theologian Bhațta Rāmakaṇtha (c. 950-1000 AD) could argue with Buddhists over the notion of

\footnotetext{
${ }^{1}$ Jullien (2007, p. 55)
} 
the self on coherent, mutually understandable grounds, is because they share a language of disputation and philosophical knowledge broadly accepted by all. ${ }^{2}$

Such ground supplies the necessary conditions for understanding. Language is key here-Rāmakaṇtha and his Buddhist opponents wrote in Sanskrit, indeed the language of debate used over the generations-but not only this, they share traditions of scriptural authority and philosophical problematics generated through the cultural and social practices of the civilization in which they lived.

It is this background or what I have called the pre-philosophical conditions of thought in the Śaiva case that I wish to examine. The pre-philosophical conditions, the necessary conditions for understanding, contain implicit anthropologies that we can detect in the literature, including an implicit idealism and cosmological views of the person constrained by wider cosmological powers. The philosophy/prephilosophy distinction is not, however, a sharp divide in the sense that many of these sources, such as the Śaiva Siddhānta scriptures, the Parākhya and Kirana tantras, offer systematic, conceptual expositions. ${ }^{3}$

Nevertheless, the distinction is useful for identifying the thought worlds out from which philosophy develops. If, as Ganeri claims, philosophy seeks to decontextualize ideas and treat them outside of history, then this is a marked characteristic of philosophy ${ }^{4}$ and a central feature of philosophical theory along with the development of argument and reason.

While both revelaed text or scripture and philosophy may operate within a broad cultural rationality, philosophy is more systematic and directional in its argumentative strategy: philosophy needs to be a universalizing mode of thinking, whereas pre-philosophy, while being within a rational paradigm, is less systematically engaged in a dialogical or even confrontational enterprise. Pre-philosophy is a deeper resource of rational reflection that persists through time and is more concerned with categorization than reasoning per se. This pre-philosophy/philosophy division that is consonant with categorization/reasoning, is close to Heidegger's distinction between worldview (die Weltanschaung) and philosophy, where philosophy has developed out of worldview, the difference being that, according to Heidegger, philosophy aims at achieving a universal understanding of life. ${ }^{5}$ My appeal to Heidegger is not to impose his distinction on the Indic material but to exemplify the difference between pre-philosophical and philosophical discourse. We can legitimately distinguish philosophy from the ambient thought world articulated in revealed texts, in which philosophy exists, which it presupposes, and which provide the necessary conditions for understanding. The questions of philosophy concerning the nature of the person are explicit and reflective in

\footnotetext{
${ }^{2}$ Watson (2006, pp. 51-69). Cabezon calls this intellectual context Scholasticism. Cabezón (1998). On the dialogue between the non-dual Śaivas and the Buddhists see the definitive book on the Pratyabhjñā by Isabelle Ratié (2011).

3 Indeed, scriptures such as the Kirana-tantra were inspired by philosophical schools, particularly Sāmkhya. See Goodall (1998, p. li). The Parākhya (1.5), for example, offers a programmatic treatment of five topics, the bound soul (paśuh), the Lord (iśvarah), pure knowledge (vidyā), and liberation (muktih). Goodall (2004, pp. 139-140).

${ }^{4}$ Ganeri (2001, p. 4).

5 Heidegger (1988, pp. 8-11).
} 
contrast to a general awareness of self, or implicit philosophies of the person in prephilosophical literature; as Ratié observes in relation to the Pratyabhijñā, I know that I am myself, but philosophy articulates the problem that I do not know what I am. ${ }^{6}$ Pre-philosophy can offer categorization to show how a person fits in to the grander cosmological structure but only philosophy offers reasoned arguments as to why this should be the case.

\section{(b) Implicit Anthropologies}

Over the last thirty years or so there has been a great deal of work done in the social sciences and humanities focused on the body and there is an extensive literature on this. ${ }^{7}$ While this shift of focus has been in many ways commendable and has supported questions being asked about the past that have contemporary relevance, concerning, for example, gender equality and social justice, I would, however, like to shift attention from the category 'body' to the category 'person' because this allows us to look for the relational and social nature of persons and the ways they are embedded in the historical longue durée. The 'person' - at least in the Western sense of embodied social actor - is not a privileged category in Indic thought; rather Indian philosophy tends to focus on the category of the self (atma,$j \bar{\imath} v a h$, purușah), impersonal absolute (brahma), or being (bhāvah), but using the category 'person' as a lens through which to view textual material from the past, allows us to examine not only ideas about body, but ideas about self and moral agency too. ${ }^{8}$ It also allows us to raise philosophical questions about historical understandings of person, and whether the category can be legitimately used as a lens through which to view the world of the text. An implicit anthropology is a theory of persons that might remain unthematized in a culture, to uncover which is the task of the analyst. In exposing pre-philosophical, implicit anthropologies we are inevitably using a prima facie notion of person as operating in moral and legal discourse. That is, the category 'person' is more than a synonym for 'human being,' as Charles Taylor observes,

\footnotetext{
6 The Pratyabhijñā philosophers claim to transform a delusional insight about one's sense of self, who I am, into a recognition of one's true nature. Ratié puts this well, that I know that I am myself but the nature of what I am escapes me. This is an alienation that deprives me of a freedom that only the complete realization of my true nature can restore to me, that the Pratyabhijñā philosophy claims to provide. The Netra-tantra does not articulate this idea but is nevertheless orientated towards a non-dualistic view in chapter 8. Ratié identifies the Pratyabhijñā position succinctly: 'Je sais que je suis moi-même - faute de quoi je n'aurais pas à me reconnaître. J'ai conscience de mon identité, et c'est cette conscience qui sourd dans toute reconnaissance de soi, mais l'essence qui rend possible ma permanence en tant que sujet m'échappe. Et c'est parce que, tout en sachant que je demeure le même, j'ignore ce qui fonde réellement cette identité, que je suis un être souffrant, asservi, aliéné au sens propre du terme: c'est dans la mesure où je demeure étranger à moi-même qu je suis privé d'une liberté que seule peut me restituer la réalisation complète de ma véritable nature. Les philosophes de la Pratyabhiñā opposent ainsi à la reconnaissance de soi ordinaire, présenteé à la fois comme l'indice de ma véritable identité et comme le symptôme d'une fondamentale méconnaissance de soi, une Reconnaissance d'un ordre supérieur parce qu'elle implique la prise de conscience complète de définitive de ce que je suis.' Ratié, Le Soi et l'Autre, pp. 5-6.

7 See, for example, Turner (1984), Shilling (1993), Coakley (1997) and Feher et al. (1989). With the focus on the body in Indian religions we have: Boullier and Tarabout (2002), Botto et al. (2004) and Michaels and Wulf (2011).

${ }^{8}$ On the idea of categorization see Frazier (2014).
} 
because it entails a being with certain capacities, such as language, such as being the bearer of rights, such as having a sense of self and identity. ${ }^{9}$

Many years ago, Michael Carrithers, Steven Lukes and the late Steve Collins published a collection of papers responding to Marcel Mauss' essay 'Le concept du soi,' in which Mauss argued a case for a developmental scheme leading up to the notion of a person as a citizen with rights and legal status in contrast to the earlier understanding of person as simply a role or mask (personnage). Mauss claimed that the notion of the person never developed in India in spite of potential. Of particular importance in this collection was Alexis Sanderson's essay 'Purity and Power Among the Brahmans of Kashmir' that challenged Mauss and changed the way we think about the history of medieval religion in India. In this essay, Sanderson posited the distinction between what we might call two realms of discourse, the realm of Brahmanical purity and the realm of Tantric power that opposed it. Sanderson claims, contra Mauss, that the Brahman of classical Indian religion is 'the most individual of individuals' concerned with the protection of boundaries around the self and focused on his ritual purity. ${ }^{10}$ By contrast the extreme Śaiva ascetic transgressed the boundaries of such purity in pursuit of magical power and ecstatic mysticism. Sanderson presents a spectrum of cultural values from orthodox vaidika dharma to heterodox tāntrika sādhana, with a range of texts from orthodox practice in texts of Dharma to the extreme 'power end' of the spectrum with transgressive Kaula texts such as the Brahmayāmala. ${ }^{11}$

While Sanderson's essay has been significant in understanding the history of Indian religions, and the distinction between purity and power is an important one, I wish to capture something more of what post-Gupta or medieval tantric texts understand a person to be. If we look more closely at Sanderson's view that the Brahman at this time is highly individualistic, this means that he is the bearer of certain obligations and capacities to behave in accordance with an understanding of himself and the world he lives in, generally to live in ways consonant with duty, with vārnāśrama-dharma, ${ }^{12}$ and to pursue legitimate goals of life (purușārthah) of duty (dharmah), success (arthah), and pleasure (kāmah) and even, perhaps finally, salvation (moksah). ${ }^{13}$ This is the orthodox Brahman conforming to the cultural values of the wider society. But there is also the tantric practitioner seeking power

\footnotetext{
9 Taylor articulates well what the English word designates: 'A person is a being with a certain moral status, or bearer of rights. But underlying the moral status, as its condition, are certain capacities. A person is a being who has a sense of self, has a, notion of the future and the past, can hold values, make choices; in short, can adopt life-plans' (Taylor (1985, pp. 97-114). While we cannot assume that this conceptualization is shared across cultures and throughout history, it is a succinct summary of what the word 'person' indicates, from which one can begin to measure differences and similarities in other contexts. It seems to me that the category of the person as having moral status and certain capacities, such as language, reason, and judgement, is a necessary assumption for such inquiry.

10 Sanderson (1985, pp. 190-216).

11 Sanderson, 'Purity and Power': 'We see that the forces of self-representation in the Kashmirian community of this period, manifest in the poles of this duality of the orthodox and heterodox and in the dialectic of their convergence, were contained within a fundamental structure of values which, arguably, underlies a far wider range of cultural forms in the kingdoms of medieval India' (p. 192).

12 Sanderson (2019, pp. 1-48).

13 On the importance of these values see McClish (2019, pp. 150-170).
} 
and tantric texts present a view of the person as having relinquished limited Brahmanical agency for supernatural abilities; thus, in the Krama tradition of Kālī, as Sanderson shows, the practitioner dissolves inhibition to experience true autonomy in his identity with autonomous consciousness. ${ }^{14}$ Alongside the orthodox Brahman and the tantric practitioner, we also have the socially marginalised (women and lower castes) who fall outside of the Brahmanical code.

With this background in mind, the argument I wish to develop is that the implied category of the person in the Netra-tantra exemplifies a range of views of person as bearer of capacities from making choices and being directional towards an eschatological goal, to a being whose choice-making capacity has been removed through supernatural intervention. This distinction between person as agent in control of their choices and life direction, in contrast to person as passive receiver of another's agency to their distress and potential death, is arguably linked to social status. The Brahman tantric practitioner who seeks power and liberation is a person in charge of their life, developing certain capacities through participation in a tradition of practice. The non-Brahman who becomes possessed by a goddess has relinquished agency, has given voice over to another power, although we must not forget the case of intentional relinquishing of agency in controlled possession. ${ }^{15}$ There is arguably a case here, that those occupying lower social status or those on the social margins find voice or enter into mainstream discourse through possession (see below).

The Netra-tantra contains both models of the person; the person as agent with capacities for developing spiritual practices whose goal lies in a vertical direction of world transcendence, along with the person who is afflicted by supernatural power such that he or she has relinquished agency. The reason for choosing this text in answer to questions about early medieval views of a person, is because it contains this spectrum of understanding. The sociological reality of these implicit anthropologies comes to articulation or becomes transformed as philosophical argument and speculation.

But both the agential self of the tantric Brahmanical practitioner and the passive self of the possessed are themselves set within a broader anthropology that we might characterise as a cosmological view of a person: the view that each person in social relationships is the subject of massive forces beyond them, a cosmological hierarchy that controls each level of the universe into what it is. ${ }^{16}$ Even the Brahman agent is the recipient of past karmic action but is not determined by those actions because the powers of the person recapitulate the powers of Siva. ${ }^{17}$ The person in this traditional cosmology contains an imago dei and through spiritual practices such as those of the supreme and subtle meditations in the Netra-tantra, he recognizes this within himself through Śiva's grace, and, for the Netra-tantra, in so doing is freed.

\footnotetext{
14 Sanderson, 'Purity and Power,' p. 199.

15 For a contemporary account see Freeman (1998, pp. 73-98).

16 This important question of the what are the constraints that control an outcome into its particularity is raised by Bowker in his work. See Bowker (2015, pp. 146-164).

17 It is not possible to develop this here, but Śiva has five capacities of creation maintenance, destruction, concealment and grace that are recapitulated in the person. See Kṣemarāja, Pratyabhijñāhṛdaya sūtra 10.
} 


\section{(c) Methodological Principles}

Lastly in these introductory remarks, I need to say something about methodological principles through which such a claim can be established. The fundamental principle is to work upwards to structurally or conceptually higher levels through paying close attention to the texts and where possible or practicable, to working with manuscripts themselves. The study of textual passages lends support to an argument about implicit anthropologies or views of person of which the text is an index. But it is not as though the scholar comes to the text in a completely objective way, because the questions brought to bear on the material are usually from a wider context outside of the text, the context of scientific inquiry and of philosophical questions relevant to the context of inquiry. But once raised, the methodological principle must always be to pay attention to the text, and scholarship (philological methods of inquiry for example) can create the conditions in which the meanings of the text can be revealed. This is a letting be seen that which shows itself; a first level phenomenology of paying attention to what shows itself. ${ }^{18}$

So, we bring to bear our philosophical concerns about the nature of the person to the historical, textual material and address those concerns through a philological approach that allows the text to speak. Through this kind of attention, we see that our questions about the nature of the person do indeed develop dimensions of the text that might otherwise remain unthematized. Thus, with the Netra-tantra, in paying attention through close reading, we are able to see what it says concerning our questions about the nature of the person. The text points both to a sociological understanding of persons in relation to each other in the wider society and culture and also to a philosophical understanding or to ontological commitments about the nature of person. I argue that in the Netra-tantra this conceptualisation is eschatological in orientation and progressive, in the sense that one conceptualisation implied in the chapter on gross meditation in which person is subjected to externalised forces, gives way to the subtle meditation in which the person is suffused with power from within, to the acme of the supreme meditation in which person is identified with God as cosmic agent. These are implicit anthropologies, models of person, that could form the basis of further work of comparison; the analysis of anthropologies within or even between civilizations or measuring the textual accounts against normative, philosophical argument about persons (which this paper does not do).

Having hopefully clarified what I mean by pre-philosophical discourse, implicit anthropologies, and the methodological principles underlying the inquiry, we can begin with an account of the intellectual object of this inquiry, the text itself.

\section{The Netra-tantra}

The main source of my reflection will be the Nepalese recension of the Netra-tantra. The Netra-tantra is a text, as Sanderson shows, in the middle ground between the extremes of antinomian tantric practice of the Kaula and Krama sects and what

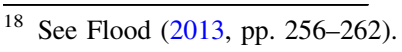


Abhinavagupta perceives as purity obsessed concerns of highly orthodox Brahmans. According to Sanderson the Netra-tantra was composed in Kashmir between 700 and $850 \mathrm{AD}^{19}$ and there is a Nepalese recension of the text preserving an earlier version than the Kashmir witnesses. The earliest manuscript, the Amrtiśvara-tantra (Na), is dated as being copied by pandit Kīrttidhara for Viśveśvara who commissioned the copying, in February/March of samvat 320 in the Nepāliya system, thereby dating it to $1200 \mathrm{AD} .^{20}$ This is the principal witness and archetype of the Nepalese recension, written as a palm leaf manuscript in a Nepalese variant of a proto-Bengali script, with an ectype $(\mathrm{Nb})$ on paper in devanāgarī. The Netra-tantra goes by the names of the Amrteśvara-tantra or the Amrtiśvara-tantra and also the Mrtyuñjit and Mrtyuñjaya. ${ }^{21}$ The Nepalese archetype (Na) that I use here calls itself the Amrtiśvara-tantra while the ectype $(\mathrm{Nb})$ calls itself the Amrteśvara-tantra. The only printed version of the text is the Kashmir recension; the Nepalese recension only currently exists in manuscript form without Kșemarāja's commentary. Only the Kashmir recension includes the commentary (Uddyota) by the Pratyabhijñā philosopher Kṣemarāja (c. 1000-1050 AD), which itself bears witness to the text's importance in his bringing it into the orbit of his non-dualist metaphysics. All four manuscripts in Sărada script that I am aware of from Kashmir contain the Uddyota. $^{22}$

In quoting from the text, I present a positive apparatus, citing the Nepalese witnesses and citing the Kashmir published text where there are differences. I sometimes refer to Kṣemarāja's commentary on the Kashmir recension as an aid to understanding, although we need to be cautious in that he attempts to impose a univocity on the text consonant with his non-dualist metaphysics. Indeed, he

\footnotetext{
19 See the Appendix, Sanderson (2004, pp. 229-300).

${ }^{20}$ Amrtīisvaratantra f. 89v4-5: Viśveśvara was the author of an initiatory text, the Amṛteśvaradīkșāvidhi, a Nepalese text on initiation and ritual for the royal family and specifically for the initiation of the kings Arimalla (b. 1153, r. 1200/01-1216) and/or his son Abhayamalla (b. 1183, r. 1216-1255) for whom the text would have been copied (Sanderson 2005, p. 241-42). Indeed, the latter had himself composed a ritual manual on regular worship after initiation (Sanderson 2005, p. 242). Kïrttidhara writes at the conclusion of his work (f. 89): 'This injunction by the Lord of Immortality, Mrtyuñjit, is completed, full, and auspicious. This book, commissioned by Viśveśvara, was written by me, the scholar Kīrttidhara, in the bright fortnight of the month of March/April, 320.' (samāptam idam mrtyuñjidamrtisisvidhānam sampūrnam iti śubham. samvvat 320 caitra śudi 9 śanidine++ viśveśvaralikhāpitam idam pustakam paṃditakīttidharalikhitam mayā).

21 Abhinavagupta cites the text three times in his Tantrāloka under the name of Mṛtyuñaya (16.59 and 224; 21.11) and under the name Netra (citing 8.30b) in his Íśvarapratyabhijñāvivrtti-vimarśini vol. 3 pp. 311 and 313. References from Brunner (1974, pp. 125-197), herself citing Lilian Silburn.

22 The Netra-tantra was first published in the KSTS in 1936 (vol 46) and 1939 (vol 61) edited by Madhusūdan Kaul based on two manuscripts, although he gives no details of them. There are four manuscripts, along with Kṣemarāja's commentary, to my knowledge in the Oriental Research Library, Srinagar. These are publicly available in digitized form at http://www.archive.org courtesy of eGangotri and McIntosh Skipper Roth. All are on paper and so later than the Nepalese witnesses.
} 
comments on it in order, he says, to bring the text within the sphere of his Sākta inspired non-dualism as Alexis Sanderson shows. ${ }^{23}$ But the Netra-tantra resists such monoglossic interpretation as it gives voice to distinct perspectives, as I hope to show here. My conclusion will lend support to the view that pre-philosophical Śaiva literature such as the Netra-tantra contains distinct anthropologies, views of the person that functioned in different social and religious contexts.

I have chosen to privilege the Nepalese witnesses for conceptual reasons, that it expresses a range of perspectives which contain contrasting, if not conflictual, views, and because the Nepalese recension reflects an earlier stage of the text's development. While there are mostly not significant semantic divergencies from the Kashmir editio princeps, there are some (such as 7.13 where the use of the different verbs virecayet and nirodhayet might indicate different conceptualisations, as we will see). Furthermore, through referring back to manuscript sources whose date we know, we are on surer ground of making claims about the text during a particular period. There is also a methodological principle that ideally, we refer to source material where possible, which means we examine manuscripts. Privileging the Nepalese witnesses over the Kashmir witnesses is justified on those grounds. Thus, the oldest Nepalese manuscript $(\mathrm{Na})$ is the editio princeps of that recension. I will draw into the discussion parallel passages from other sources, namely scriptures of the Śaiva Siddhānta, Non-dualistic Śaivism, and some yogic texts (see below for details of precisely which sources and the primary source section of the references). I do this because these parallels lend support to the presentation of implicit anthropologies in the Netra-tantra and indicate that what the Netra-tantra exposits is not idiosyncratic but can be taken as a sign of wider conceptualisations and practices at the time of its formation and during the time of its transmission. ${ }^{24}$

Often the Kashmir reading is better semantically and grammatically, but in the following quotations I have preserved the Nepalese recension as it stands, noting the Kashmir edition variants, which allows modern readers access to the basic textual material from which ideas of personhood can be generated. Alexis Sanderson has shown how the text was primarily connected with royalty and used in the courts of kings by Śaiva officiants in the role of the royal priest or rājapurohita. That Śaiva and Mahāyāna gurus performed 'apatropaic, restorative and aggressive Mantra rituals' for the protection of king and kingdom is well attested in the kingdoms of

\footnotetext{
${ }^{23}$ Sanderson (2007, pp. 231- 582): ‘... Kșemarāja stresses that his motive is to re-establish what he sees as the true, non-dualistic perspective of these texts [such as the Netra-tantra], which, he says, had been overshadowed by the prevailing view, that of the Saiddhāntika dualists, an unjustifiable inroad into nonSaiddhāntika territory that had both imposed a less enlightened reading of their teachings and led to the suppression of elements of non-dualistic practice (advaitācārah), such as the offering of fermented liquor to Svacchandabhairava, that were vital to the proper performance of their rites' (p. 398).

24 We know, for example, that it was copied for the King of Nepal in 1200 and that further texts came from it focused on practice, namely Amrteśvarapujjanavidhi, a ritual manual based on the Netra, a palm leaf manuscript in Newari script, dated Nepalīya Samvat 336 and Vikrama 1273, thus dating it to 1216 or 1217. There is also the Netrodbhava dated Nepalīya Samvat 279 and so is dated to 1159 AD before, or contemporaneous with, the copying of $\mathrm{Na}$.
} 
south and south-east Asia from the ninth to eleventh century and the Netra-tantra is a text that bears witness to Śaiva gurus in the service of kings. ${ }^{25}$ The principal use of the text would have been the protection of the king and his family through the propagation of its ritual procedures and particularly the recitation of the netra mantra. The text was first brought to our attention by Hélène Brunner who describes each chapter in some detail in her 1974 paper; ${ }^{26}$ a useful source for not only the contents of the text, but for her comments on its structure and relation to other texts. It is probable that the Netra-tantra was composed over a long period of time and the final redactors are bringing together diverse elements into a whole. David White argues that the oldest or original section of the work is the material concerned with possession and exorcism ${ }^{27}$ and this systematic treatment of possession is indeed a notable feature of it, akin to similar treatment in the Iśānaśivagurudevapaddhati. ${ }^{28}$

The central deity of the Netra-tantra is Amriteśvara, named Amritiśvara or Amrtīisa in the Nepalese recensions, also known as Amṛteśabhairava, Mrtyunjit, and Mṛtyuñjaya, whose consort is Lakșmī/Śrī called Amṛtalakșmī in ritual manuals based on the text. ${ }^{29}$ After an initial chapter in which Amrteśvara, referred to as Bhairava, responds to the questions of the Goddess by extolling the virtues and powers of Śiva's eye, the text presents a number of meditations on a number of deities, catholic in its range, not only from the systems of the Mantramārga but from Vaiṣnava traditions as well. ${ }^{30}$ The Netra-tantra is an amalgam of material including descriptions of meditations on a range of deities and their systems, yogic practices, possession and exorcism, and theological reflection. I wish here to identify concepts of the person within this material that provide evidence for the common worldview from which later Śaiva philosophers developed their arguments.

Within the Netra we can identify three implicit anthropologies, three models of what a person is, that I shall call permeable, processual, and gnostic views of the self. What concerns me here is not so much the deity visualisations, nor the chapters on possession, but three chapters that form a group: the chapters on the gross (sthūla-), subtle (sūkșma-) and supreme (para-) meditations (dhyānam), six, seven, and eight. It seems to me that this threefold hierarchical structure is an attempt to order a range of practices and understandings of the person, that the Netra is incorporating and it does so with some coherence, the lowest level of meditation practice being concerned with magical protection, the subtle level with the visualisation of the body and the powers moving within it, and the supreme meditation being principally a gnostic reinterpretation of the 'limbs' of classical yoga and understanding the self's identification with Siva. The subtle meditation is especially interesting because it presents two different systems of visualisation, one in which subtle energy rises up through the body and a second in which that same

\footnotetext{
25 Sanderson, 'Religion and the State,' p. 233.

26 Brunner, 'Un Tantra du Nord: le Netra Tantra.'

27 White (2012, pp. 145-171)

28 ISG Mantrapāda, 2.42,3b-8.

29 Sanderson, 'Religion and the State,' p. 239, n. 18.

${ }^{30}$ For example, it describes Nārāyaṇa as a naked, ithyphallic youth, a 'handsome child' (bālarūpaṃ), standing on a ram (13.10-13b), as well as visualisations of Tumburu and his sisters (chapter 11).
} 
power rising through the body releases nectar at the crown of the head that then floods the body. ${ }^{31}$ Kṣemarāja calls these the tantraprakriy $\bar{a}$ and the kulaprakriya respectively. This distinction is significant in so far as the former was the practice developed within non-dual Śaivism for the married householder that involved a regime of worship after initiation $(d \bar{\imath} k s \underline{a})$, while the latter involved worship focussed on the Goddess and entailed transgressive ritual, such as making offerings of impure and sexual substances to the Goddess, and signs of possession at initiation. ${ }^{32}$ The Netra-tantra is influenced by Śăkta tradition, and although there is indication of the kulaprakriya in the visualisation of the subtle body, there is no erotic worship in the Netra that the term kulaprakriya $\bar{a}$ usually implies, referring to the practices of the Kaula secret societies of Kashmir. ${ }^{33}$ The Netra-tantra sees itself as universal in its practice and sees itself as transcending the other branches of Śaiva scripture. ${ }^{34}$ This universality means that the text absorbs different systems and traditions. Thus, the Netra-tantra attempts to incorporate different models of the self into a coherent world picture and it does this through creating a hierarchy of practice in which the gross, subtle and supreme meditations exemplify three distinct understandings of the person, three distinct anthropologies. Brunner regards these three meditations as progressive for the tantric practitioner or Sādhaka who follows a path of seeking power having undergone a specific consecration after initiation. The Sādhaka is impregnated with the power of his mantra and can unite with his power or Śakti through the process of practice that follows a hierarchical sequence exemplified by the three chapters of the Netra-tantra under consideration here. ${ }^{35}$ The Netra-tantra uses the term and is familiar with the distinction between the Ācārya and the Sādhaka ${ }^{36}$ (e.g. 5.3) and while it does maintain a hierarchy of practice, the gross meditation is less concerned with the practitioner's spiritual development and more with protection and exorcism.

But let us set the scene with two opening verses from a later section of the text, the longest chapter nineteen, on possession. The Goddess is asking the Lord Amṛteśvara about the supernatural goddesses who can possess people.

\footnotetext{
31 I have benefitted from Bäumer's excellent study and translation of chapters seven and eight. See Bäumer (2019).

32 See Sanderson 'The Śaiva and Tantric Traditions,' p. 682.

33 Sanderson, 'Purity and Power,' pp. 203-205.

34 Netra-tantra chapter 1, Na f. 3, colophon. The text calls itself the essence of the collection of all the streams of revelation (sarvasrotasamgrahasāram).

35 Brunner (1975, pp. 411-443).

36 E.g. NT 5.3: ... adhikārārtham ācārye sādhake siddhikāmatah // 3 // 'For the teacher, his purpose is authority, for the Sādhaka, his desire is power.
} 


\section{The Permeable Self}

19.2. idānīṃ śrotum icchāmi saṃśayaṃ me hṛdi sthitam/dṛṣtipātam prakurvanti jantūnāṃ mātarạ̣ sadā // 19.3. asaṃkhyātās tu tā devyo hy aprameyabalānvitāḥ/chāyāchidreṇa bādhante yoginyo balavattarāḥ //37

19. 2-3. Now I want to hear [the dispelling of] doubt remaining in my heart, [how] the mothers are always casting an eye on people. Those goddesses are truly innumerable, furnished with immeasurable strength. The Yoginīs, possessing greater strength, force [their way] through the hole of the shadow.

Immediately we see what we are up against. The person's ambient environment is pervaded by supernatural powers that constantly threaten misfortune. ${ }^{38}$ I have translated drstipāta literally here, although Brunner renders the term as 'the evil eye' (le mauvais oeil), ${ }^{39}$ no doubt following Kṣemarāja’s gloss as jighāmsayā nirīkșanam, a look with a desire to harm, which clearly seems to be what the term means in this context. ${ }^{40}$ I have rendered the chāyāchidrena as a genitive tatpuruṣa, 'through hole of the shadow,' or it could also be rendered as a karmādharaya, 'by means of the hole which is the shadow.' But Kṣemarāja takes chāyā and chidram as distinct terms. Shadow for him seems to mean that if a shadow were to be cast by women during their courses, or during parturition, or wicked people, this could be a cause of possession. The 'hole' he declares to be beings crying in the forest. In this case, we might render chāyāchidrena as a dvandva compound, as Kṣemarāja does, that the Yoginis attack 'through the hole [which denotes] beings crying in the forest, and through the casting of a shadow. ${ }^{41}$ The shadow here is the vulnerable entry point, the point of permeability in which external powers can become established within the person. All beings are subject to this kind of affliction, and the text particularly notes the kings, princes, and queens who are afflicted by sudden death and 'killed by the snares of time' (kālapāśair jighāmsitāh $),{ }^{42}$ or if we are to take the desiderative meaning of jighāmsitāh seriously, become desirous of being

\footnotetext{
37 NT 19.2-3. Na f. 60, Nb f. 39. 19.2ab: samśayam] Na, Nb: samíayo K; sthitam] Na, Nb: sthitaḥ K; 19.2cd: jantūnām] Na, Nb: manuje K; 19.3ab: aprameyabalānvitāḥ] $\mathrm{Na}, \mathrm{Nb}$ : hyaprameyabalānvtāh K. I am grateful to the readers for their comments on this passage and for discussion with Wernicke-Olesen.

38 On the yogin̄īs see Törzsök (1999).

39 Brunner, 'Un Tantra du Nord,' p. 175.

40 But the term does not always have a negative connotation. For example, in the Lakșmi-tantra 21.26ab the mantras lead (nayanti) the man with controlled senses who is under the gaze of the teacher ( $\bar{a} c \bar{a} r y a-$ drștipāta-stham purușam samyatendriyam) where the dṛstipāta is clearly of benefit.

${ }^{41}$ NTU vol. 2, p. 128 by Kșemarāja: 'The shadow is the reason for possession of praised people by elemental spirits and so on, being given by the most wicked, by [women] who have given birth, and by [women] during menses. The hole [refers to] beings who cry in the forest.' chāyā rajasvalāsūtikāpāpișțādibhir dīyamānā praśastasya jantor bhūtādisvīkrtihetuh, chidram aranye rodanādi. Brunner thinks that we cannot interpret chidram literally as 'hole' but that it conveys the idea that the shadow can bring up from the ground elemental spirits that can attack vulnerable people. Brunner (1975, p. 175 , note 2 ).

42 NT 2.15ab.
} 
killed by the snares of time. Hence there is need for magical protection against such eventualities and the text supplies this in the gross meditation.

In the opening verses of the sixth chapter, Amriteśvara speaks of how poor people are assaulted by these terrible powers, stricken with anxiety, disease and danger, and that through the threefold method comprising the gross, subtle and supreme meditations they are freed from those killers. ${ }^{43}$ The text regards these three as a complete system that correspond to the threefold method mentioned earlier in the text in chapter two, namely knowledge, yoga and mantra, that bestows liberation and powers. ${ }^{44}$ The gross method that comprises ritual action such as fire offerings, mantra repetition, ritual gestures and so on, for defence against supernatural incursions, is formed by the King of Mantras, namely the netra mantra. ${ }^{45}$ The ritual procedures for the purpose of warding off affliction (pratighātārtham) ${ }^{46}$ are described, writing the name of the person to be protected, and offering white substances such as sugar, butter and milk into a fire pit. ${ }^{47}$ With such ritual procedures accompanied by repetition of the mantra, the emaciated body will come back to health instantly, and even previously ineffective mantras can be enlivened by being framed by the netra mantra. ${ }^{48}$ The weak man, full of disease, when looked after will be released through repeating his name framed by the netra mantra. ${ }^{49}$ The text describes a number of other ritual procedures for curing affliction and gaining prosperity such that a barren woman may become fecund, a daughter may find a husband, and the king obtain a prosperous kingdom and long life, strength and fame. $^{50}$

This is a world in which the boundaries of person are permeable (as arguably was the case in all pre-modern societies), in which the normative goals of fulfilling one's social obligation, worldly success, and enjoying pleasure, attested in other kinds of literature such as the Brahmanical Smrtis and texts of the Sivadharma genre, are to be preserved from adverse supernatural interference. ${ }^{51}$ The inevitability of human misfortune is explained through a model of self in which human agency is limited because of the threat of such incursions in which the person is almost the passive recipient of external forces. In the Netra, agency is invested in the wielders of counter powers, the mantrins or masters of mantra, who protect and expel obstacles to success in life, where 'obstacles' are indeed supernatural powers, the Vighneśas. This worldview pervades all social levels as we see here, the Netra being

\footnotetext{
$\overline{43} \mathrm{NT}$ 6.5-6. Na f. 12 recto - f.13 verso, Nb f. 9: apamṛtyuśatākrāntā janā dāridryasamyutāh ädhivyādhibhayodvignāh pāpaughair vinipị̣itāh // 5 // mucyante tu yathā sarve pūrvoktair māranaih priye/ trividham tad upāyam tu sthūlam sūkșmam param ca yat // 6 //. 6a: tu] Na, Nb: ca K; 6b: māranaih] $\mathrm{Na}, \mathrm{Nb}$ : dārunaịh $\mathrm{K} ;$ 6cd: yat] $\mathrm{Na}, \mathrm{Nb}$ : tat $\mathrm{K}$.

44 NT $2.7 \mathrm{~b}$

45 NT 6.7. The construction of the netra mantra, OM JUM SAH, has been described in chapter two.

46 NT $6.9 \mathrm{c}$

47 NT 6.11cd-12ab.

48 NT 6.17-20.

49 NT 6.18.

${ }^{50}$ NT 6.46-48.

51 Sanderson (2009, pp. 41-350).
} 
particularly concerned with the royal household; a worldview that was not restricted to Kashmir or Nepal but extended probably throughout the subcontinent in the early medieval period and is attested in Kerala where the Śaiva Siddhānta text, the Iśānaśivagurudeva-paddhati bears witness to similar concerns, presenting a typology of possessing beings, similar to the Netra, along with prescriptions for their expulsion. We can read in these texts, indices of attitudes towards caste and gender as well. The ISG, for example, describes children and women in certain conditions, such as menstruating, laughing loudly, when naked, or 'standing at a crossroads' (prostitutes?) as being particularly vulnerable to possession, along with those who transgress caste boundaries, such as people in lower social strata pretending to be Brahmans. ${ }^{52}$ This would be a worldview pervasive of all social levels and these texts articulate a sense of person that is the basis for the development of systematic reflection on the nature of the self that we find in philosophical literature. But with the chapters on possession, we arguably also have the expression at a discursive level of the concerns of marginalised social groups who would otherwise not have voice, particularly important as it comes in the guise of revelation. 53

\section{The Processual Self}

A second model of person is articulated in the Netra's subtle meditation. We might call this a model of the self as processual in the sense that rather than a focus on the permeable boundary between self and cosmos, this is a wholly internalized conception of self in which cosmological powers move within the body and the practitioner, far from being a passive recipient of invasive powers from outside the body, consciously controls power within the body. Indeed, through yogic practice the practitioner activates a process in which power is awakened and rises up to the crown of the head, as in standard later yoga tradition. ${ }^{54}$ But the Netra-tantra posits two systems of meditation related to an indigenous classification of traditions into the system (prakriyā) of tantra- or kula-, which both entail slightly different understandings of person.

In chapter seven on the subtle meditation the body is immediately presented as a hierarchical structure for the support ( $\bar{a} d h \bar{a} r a$ ) of the soul, pervaded by various loci of power, the six 'seasons' or centres, twelve knots, five voids, three luminous abodes, and so on. ${ }^{55}$ But there is a contrast between the impure body and the purified body that becomes divine, which the Yogin needs to achieve.

\footnotetext{
52 ISG Mantrapāda, 2.42. 3-8.

53 See the classic argument that we find possession in marginalized groups, by Lewis (1971): 'In peripheral cults these pressures arise from the oppression to which subordinate members of the community are subject' (p. 176).

54 See Padoux (2002, pp.163-187). Also, Flood (2011, pp. 70-83).

55 NT 7.1-3. Na f. 15, Nb f. 10: atah param pravakșyāmi dhyānam sūkșmam anuttamam/ṛtușaștha svarādhāram trilakșam vyomapañcakam //1// granthidvādaśasamyuktam śaktitrayasamanvitam/dhāmatrayapathākrāntam nāḍtrayasamanvitam //2// jūātvā śarīrạ̣ suśroṇi daśanāḍipathānugam/ dvāsaptatisahasrais tu saptakoțārdhasamyutaṃ//3// 7.1c ṛtușaștha] $\mathrm{Na}, \mathrm{Nb}$ : ṛtucakram K; 7.1d
} 
7.4. nāḍivṛndaiḥ samākrāntam malinaṃ vyādhibhir kṛtaṃ/sūkṣmadhyānāṃrtenaiva parenaivoditena tu // 7.5 āpyāyam kurute yogī ātmano'tha parasya ca/divyadehas tu bhavati sarvavyādhivivarjitah $/ /^{56}$

7. 4-5. [The body] is impure, overrun by a multitude of channels, riddled with diseases, but the Yogin then fills his highest self with the nectar of the subtle meditation that is proclaimed as the highest; he becomes a divine body bereft of all disease.

Here the contrast is stark between the disease-ridden body and the divine body bereft of disease that the Yogin seeks to attain. Thus, there is a resonance with the previous chapter in that both the gross meditation and the subtle seek to transform the body through the expulsion of disease caused, in the first case, by the intrusion of malevolent entities. This account is not incompatible with that view and seeks the transformation of the Yogin so that he becomes full or complete. In the sentence äpyāyam kurute yogī, while Brunner's 'le yogin redonne vigueur' ${ }^{57}$ is of course correct, the term appyayam conveys the sense of expansion or filling; in the Kashmir recension, the Yogin becomes full himself yet can also perform this meditation for another ( $\bar{a} t m \bar{a} n o$ va parasya $c a$ ) and one suspects that it is the king who is meant here. The alternative reading of the Nepalese witnesses replaces $v \bar{a}$ with atha and so this can be taken to mean that the Yogin becomes full of the supreme self, as suggested by Wernicke-Olesen (personal communication). ${ }^{58}$

In the process, the Yogin establishes the supreme power (parā śaktih) within himself in the lowest of the bodily centres, the power that is in fact his own nature (svarūpam), his self-perception (svasamvedyam), that pervades himself (svavyāptisambhavam), is self-arisen (svoditam) and, in an obscure phrase, this power is Siva present in the Yogin's womb. The Kashmir recension of the text identifies 'his womb' with the auspicious Goddess (tadgarbhagā śivā), which Kșemarāja claims

\section{Footnote 55 continued}

trilakṣaṃ] $\mathrm{Na}, \mathrm{Nb}$ : trilakșyam $\mathrm{K} ; 7.2 \mathrm{~b}$ daśanāụipathānugam ] $\mathrm{Na}, \mathrm{Nb}$ : daśanāụipathāvṛtam $\mathrm{K} ; 7.3 \mathrm{c}$ dvāsaptatisahasrais] $\mathrm{Na}, \mathrm{Nb}$ : dvāsaptatyā sahasrais $\mathrm{K} ; 7.3 \mathrm{c}$ saptakotyādhasamyutam $\mathrm{Na}, \mathrm{Nb}$ : sārdhakotitrayena $\mathrm{ca}$ K. 'Now I will tell you about the excellent, supreme, subtle visualization [of the body which comprises] that with sixteen supports [the vowels], the six seasons, the three objects, and the five voids. 7.2. [That body is] accompanied by twelve knots, associated with three powers, perfused by the path of three luminous abodes [sun, moon, and fire, and] permeated by three channels. 7.3. Having known the body, $\mathrm{O}$ one with beautiful hips, that follows the path of ten channels, with seventy-two thousand, and 3,500,000 [channels] [the yogi can create a divine body].' I have rendered r rușaștha as 'six seasons' although șaștha means 'sixth.' The Kashmir edition reads r rtucakram where rtu is simply a synonym for 'six'. The term sūkșmadhyāna is attested elsewhere including the general, hierarchical structure of the subtle body, e.g. in the later Gheraṇ̣̂așhitā 6.18ab: tejodhyānam śrutam caṇ̣̂ sūkșmadhyānam vadāmyaham, 'You have heard the luminous dhyana, Chanda; I shall describe the subtle dhyana' (Mallinson's translation); 6.20cd sūkșmadhyānam idam gopyam devānām api durlabham, 'This subtle dhyana is to be kept secret. It is hard for even the gods to attain' (Mallinson's translation.). See Birch (2011, pp. 527-554.

56 NT 7.3-4, Na f. 15- f.16, Nb f. 11. 3b: krttam] Na, Nb: vṛtam K; 5ab ātmano 'tha] Na, Nb: ätmano vā K; 5d: $t u$ ] $\mathrm{Na}, \mathrm{Nb}: s a \mathrm{~K}$.

57 Brunner, 'Le Netra Tantra,' p. 143.

58 Also see the Wernicke-Olesen Śākta traditions website, http://saktatraditions.org/netratantra-chapter$7 /$. 
shows the identification of sakti with siva, that she is not in a dependent relationship to him, while the Nepalese witnesses retain the masculine case tadgarbhagah sivah. ${ }^{59}$ But the point is that the Yogin establishes the Goddess in the root centre of his body and forces this power into the central channel that pervades it, making her flow between exhalation and inhalation. This is also a strong sense of his own self (abhimānam), although in the end an erroneous sense. ${ }^{60}$

The text then goes on to describe two processes that Kșemarāja identifies as the system of the kula and the tantra, ${ }^{61}$ citing an anonymous Kaula text describing the centres of the body. The kulaprakriya is the system in which the Yogin raises the power within him from the centre at the base of the central channel so that it rises, piercing the various loci along the central axis of the body, to the crown of the head. Here-and this is the distinctive Kaula practice-he causes the nectar of immortality located there to flow down through the channels of the body, pervading the body, thereby filling it with the nectar of immorality that is the cause of a somatic joy. Wernicke-Olesen has identified this as a distinctive Śākta anthropology characterized by this practice of 'flooding' the body with the nectar of immortality flowing from the head (amrtaplāvanam). ${ }^{62}$ This practice is to enter the mainstream Hatha Yoga tradition such that it comes to replace the earlier system that WernickeOlesen identifies as binduyoga-Anthropology aimed at retaining semen within the head (bindudhārana), an idea central to the later practice of the khecarimudrā. ${ }^{63}$ Indeed, Wernicke-Olesen shows how the later tradition came to retain both models, ${ }^{64}$ even though contradictory to each other. Here in the Netra-tantra the kulaprakriya follows the amrtaplāvana idea while the tantraprakriya seems to be in accord with the bindudhärana. On the amrtaplāvana practice, the Netra has the following verse:

7. 13. viśrāmyānubhavam prāpya tasmāt sthānāt pravāhayet/sarvam tad amrtạ̣ vegāt sarvatraiva nirodhayet //

\footnotetext{
59 NT 7.7.

${ }^{60}$ NT 7.8. The term abhimāna generally designates an erroneous evaluation of the self, a pride or high opinion of oneself, but in the Pratyabhijñā it is taking oneself for less than what one truly is and is the root of the ego. Ratié explains this well: 'Ici, le sense du terme est en quelque sorte renversé, puisque l'abhimana dont parlent les philosophes de la Pratyabhijñā consiste à se prendre pour moins que ce que l'on est (c'est-a-dire pour un corps particulier, un intellect particulier etc, au lieu de s'appréhender comme la totalité d l'être), mais ce renversement n'est qu'apparent: le terme abhimana sugère une inflation de l'ego, or c'est cette conviction erronée qui est à la racine du sens de l'ego précisément - de la conviction d'être un 'moi' par opposition au reste du monde.' Ratié, Le Soi et l'Autre, pp. 206-207, note 76.

61 The tantraprakriya is the normative, liturgical system of the Trika tradition of Śaivism, referring to the Śaiva initiate's daily worship (nityavidhih), while the kulaprakriya represents a more esoteric tradition only for the suitable person (adhikārî̀). Sanderson, 'Maṇdala and Āgamic Identity in the Trika of Kashmir,' p. 169 note 2.

62 Wernicke-Olesen and Einarsen (2018, pp. 241-257). Also see Mallinson (2015, pp. 109-140).

63 On this see Mallinson (2007).

64 Wernick-Olesen and Einarsen (2018, pp. 249-251.
} 
7.13. After resting and having attained that experience, he should cause [the nectar] to flow from that place [and] he should forcefully hold it there everywhere [in the body]. ${ }^{65}$

The Nepalese text uses the optative nirodhayet, 'he should hold' the nectar in the body whereas the Kashmir text has virecayet, 'he should cause it to flow'. While one should be careful of not reading too much into this, it could be that the vocabulary of the text reflects an older understanding of 'holding' and controlling nectar within the body, because the Nepalese recension preserves an earlier condition of the text, whereas the Kashmir edition reflects a fully formed Sākta idea. But both would seem semantically appropriate as the practitioner causes the nectar to be suffused through the body but also keeps it there.

Kșemarāja understands this practice to be of importance. Although in his commentary he uses the term amrtārnavaplāvana ${ }^{66}$ rather than amrtaplāvana, and identifies it with the realization of oneself as the Lord of Immortality, commenting on one of the last verses of the chapter that the Yogin should meditate upon Supreme Siva as being of the nature of supreme nectar which floods the body 'in all directions,' which is to be united with the powers of will, cognition and action. ${ }^{67}$ As is his practice, he reads the text through the lens of his non-dualism. But this idea of flooding the body with nectar is attested in other sources and is often in conjunction with 'drying' (śośanam) and 'burning' (dahanam), practices of visualization in which the impure body is imagined as being dried up and then burned to ashes, followed by being flooded with nectar arising from the union of Śiva and Śakti at the crown of the head, and thereby renewed and reformed. A post twelfth century example of this is the Kaula text the Kulärnava-tantra ${ }^{68}$ which describes breathing practices accompanied by drying, burning, and flooding:

15.37. dvādaśāvarttayan tāraṃ vāyum madhye ca kumbhayet/śoṣayed vāyubījena dehaśoṣaṇam īritam //37// punaś ca pūrvavad vāyuṃ virecyāpūrya kumbhayet/dahet dahanabījena dehadāhanam īritam //38// punaś ca pūrvavad vāyuṃ virecyāpūrya kumbhayet/śivakuṇụalinīyogasyandanāmṛtadhārayā/ āpādamastakaṃ devi plāvayet plāvanam bhavet //39//69

\footnotetext{
${ }^{65} \mathrm{NT}$ 7.13, Na f. 16, recto, Nb f. 11. 7.13a viśrāmyānubhavaṃ] $\mathrm{Na}$, Nb: viśrāmānubhavam K; 7.13d: nirodhāyet] $\mathrm{Na}, \mathrm{Nb}$ : virecayet, $\mathrm{K}$.

66 NTU vol. 1, p. 175.

${ }^{67}$ NTU vol. 1, p. 175: Kṣemarāja’s commentary: tatah sarvaromakūpaih prașrtyāntarbahirāsāditavyāpti sarvadikkam amrtārṇavaplāvanasamarasībhūtaparamāmṛtarūpam, icchā-jñāna-kriyāśaktikacitam paramaśivarūpam nirāmayamātmānam cintayet. 'One should meditate on the self as free from disease, having the nature of the Supreme Siva, aligned with the powers of will, cognition and action, whose nature is the supreme nectar, whose being is the taste of sameness [resulting from] the flooding by the ocean of the nectar of immortality in all directions, being the condition of pervasion diffused through all the pores of the skin, inside and out.'

68 Sanderson writes that this text marks the development of a new kind of Kaulism claiming superiority over earlier forms. Sanderson (2012-2013, pp. 1-113).

69 Kulārnava-tantra 15.335-39.
} 
15.37. Repeating the saving syllable [OM] twelve times, [the Yogin] should retain the breath in the middle [channel, then] he should dry up [the body] with the wind-seed syllable [YAM] uttered for the drying up of the body.

15.38. And again, as before, having exhaled and inhaled the breath, he should retain it [then] he should burn [the body] with the burning seed syllable [RAM], called the burning of the body.

15.39. And again, as before, having exhaled and inhaled, he should retain the breath. He should meditate on flooding [and] should flood [the body] from head to toe, O Goddess, with the nectar held [in the head] flowing from the union of Śiva and Kundalinī.

Here we have a Kaula text that has integrated the plāvana practice with hatha yoga breath control. This association of plāvana with śośana and dahana along with its practice connected to breath control and the seed syllables for air, fire, and water is well attested elsewhere. ${ }^{70}$ In his commentary on the Svacchanda-tantra, closely related to the Netra, ${ }^{71}$ Kșemarāja gives the seed syllables associated with the practice and presents a reading in line with his philosophy. ${ }^{72}$ Thus, the practice of drying up the body is the somatic experience in which the fluid or sense of oneself as an ego is dried up $^{73}$ being replaced by the experience of non-dual awareness. ${ }^{74}$

The practice of plâvana is also integral to the daily ritual procedure of the purification of the elements within the body (bhütaśuddhi) in which, as a preliminary to the creation of a divine body, inner and outer worship, the body is burned in the imagination and the ashes washed away by the flood arising from mantra utterance. This practice is well attested throughout Śaiva literature but perhaps its best, and possibly its earliest, articulations comes with the Pāñcarātra text, the Jayākhya-samhitā, which speaks of the symbolic destruction of the body through being burned from the 'fire of time' (kälāgnih) in the big toe; the resulting pile of ashes is then washed away by the liquid born from the visualization that the

\footnotetext{
${ }^{70}$ For example, the twelfth century Śāradātilaka 4.27-28: tatah saṃśoșayed deham vāyubījena vāyunāl vahnibījena tenaiva saṃharet sakalām tanum //27// viśleșayet tadā doșān amṛtenāmṛtāmbhasāl āplāvyāplāvayed deham āpādatalamastakam //28//. 'Then he should dry the body with wind, with the wind seed mantra, with the fire seed mantra he should destroy the entire body, then he should dissolve the faults with nectar, with the fluid of nectar, flooding the body, he should inundate it from head to toe.' The commentator Rāgavabhaț̣a (composed 1494) cites a source that he names simply 'samhitā' and cites teachers (ācāryāśs ca) who say: athavā śoșana-dahana-plāvana-bhedena śodhite dehe, 'or he should purify the body with the division of drying, burning and flooding.' On the place of the text in the history of Saiva literature see Sanderson, 'Śaiva Literature,' pp. 82-83. There are other attestations of these three together, for example the Śiva Purāna 28.10cd; Maheśvarānanda, Mahārthamañjari 44; Paraśurāmakalpasūtra 3.12. Even the Śaiva Siddhānta text, the Suprabhedāgama 4.23 bears witness to 'burning and flooding' after the imposition of mantras on the hands (karanyāsah). The Bhairava tantra, the Svacchandatantra also describes the three practices 2.30-38ab.

71 Sanderson, 'Śaiva Literature,' pp. 36-38.

72 Svacchandoddyota $2.37 \mathrm{ab}$.

73 Svacchandoddyota 2.36, p. 23: tanoḥ śoṣo hantābhimānarasatanūbhāvah.

74 Svacchanddoyota $2.39 \mathrm{~cd}$, p. 25: 'plāvayet' bhairavābhedaparāmarśamayam kuryādityarthah. " "He should flood" means he should perform that which comprises the supreme awareness of the non-duality of Bhairava.'
} 
practitioner imagines flooding the directions. ${ }^{75}$ This symbolic burning of the body reflects the idea of sacrifice and even the sentiment in the Bhagavad-git $\bar{a}$ (4.37) that wisdom reduces all actions to ashes. Although the text does not explicitly say this, we may assume that the source of this milky liquid, this nectar (amrtam) is from the crown of the head where, at this stage of the rite, the practitioner's self is located. The milky ocean thereby created flows to the directions, that is, fills the body. This practice is very close to the yoga of burning and flooding the body and the inner Kaula practice of Kundialinī.

We have, therefore, three closely related practices: the Kaula plāvana attested in the Netra-tantra, the Hatha yogic plāvana performed in conjunction with śośana and dahana, and the pan-tantric, ritual practice of the bhütaśuddhi. All of these are predicated upon a particular understanding of the person that I have called processual in so far as the Yogin as the exemplar of human accomplishment undergoes a process of inner transformation or realization through a process of change in which visualization practices are thought to facilitate an existential shift in the condition of the practitioner. Philosophical articulations and arguments about metaphysics - the Pratyabhijñā arguments for the identification of self with pure consciousness for example - are predicated upon an overall model of the self as having porous boundaries and thereby being transformable through a process that entails the manipulation of powers within the body. In particular, the nectar of immortality located at the crown of the head comes to be released, filling the body with happiness and creating a sense of identification with that power. The philosophical arguments for non-dualism expressed particularly in Abhinavagupta's İ́sarapratyabhijñāvimarśin̄ and the position summarized in Kṣemarāja's Pratyabhijñāhrdaya ${ }^{76}$ are easy developments from this pre-philosophical understanding of both the porous and processual self. Both of these conceptions of self entail the idea of transhuman powers having the ability to enter into the person thereby changing their nature, either in terms of negative moral value, as in the case of the malevolent possessing deities, or of positive moral value in the case of the yogic process of imbuing the self with the nectar of immortality. Both entail a 'container' metaphor of the body ${ }^{77}$ that can be filled with powers-even conceptualized as a fluid in the plāvana case-and both entail the integration of person with structure of cosmos and also the integration of the hierarchical cosmos into the self. From the porous and processual models, it is but a small step to developing a philosophical conception of non-dualism such that, in a citation by Kșemarāja, aham eva paro hamsaḥ śivaḥ paramakāranam, 'the supreme cause is the supreme self Śiva, which is that very I [which is myself]. ${ }^{78}$ It is also reflected in Abhinavagupta's interpretation of the term samāveśa as immersion in pure consciousness rather than possession by external

\footnotetext{
75 Jayākhya-saṃhitā 10.77: dhyānajenodakenātha bhūtim saṃplāvya diggatām vinipātāt svamantrena siktena kșirarūpinā, 'Then having flooded the ashes [left from the burning of the body] he should [make the fluid] flow down to the directions, sprinkled with his own mantra, whose form is milk.' See Flood (2002, pp. 25-43).

76 On the philosophical development see Ratié (2013).

77 Lakof and Johnson (2003, pp. 29-30).

78 Svacchandoddyota 2.36, citing 4.399.
} 
power. ${ }^{79}$ The implication of this is that practices of meditation and yoga come prior to practices of philosophy in that philosophical argument is predicated upon prephilosophical assumptions and models of self that are articulated in pre-philosophical literature.

\section{The Gnostic Self}

The last pre-philosophical implicit anthropology born witness to in the Netra, we might name the gnostic self. The content of this entails the Yogin reappraising practices and understanding of normative yoga (the system of Patañjali) within what the text regards as a higher register of interpretation. While some Tantras make reference to six ancillaries of yoga (șadanga) ${ }^{80}$ the Netra refers to the famous eight. Here the ancillaries of yoga practice are interpreted to mean different states of knowledge or cognition. Thus, the chapter on the supreme meditation (paradhyānam) opens with the Yogin having identified himself with the absolute reality of Siva, who shines forth, beyond the power of speech to express that which cannot be seen by the eyes, smelled by the nose, tasted by the tongue, felt by the sense of touch, nor heard by the ears, because it is immeasurable and beyond the senses. Attaining this realization through great practice and detachment (tad abhyāsena mahatā vairāgyena parena $\mathrm{ca}$ ), Patañjali's terms, the Yogin becomes free from old age and death. ${ }^{81}$ Such attainment is consonant with moral values of abandoning passion, hate, greed and delusion and other negative qualities such as self-conceit, jealousy, arrogance and intoxication. Realizing the supreme state in the blink of an eye, the Yogin becomes liberated. ${ }^{82}$ While he attains this realization through the eight ancillaries of yoga, this is no mere mundane yogic practice of a gradual ascent to liberation, but rather the Yogin needs to understand the inner meaning of the limbs, that self-control (yamah) is really the cessation of becoming, restraint (niyamah) is constant meditation (bhāvanā) on supreme reality (pare tattve) and the other ancillaries are similarly reinterpreted. Posture (äsanam) is abiding within between inhalation and exhalation, and thereby becoming established in the power of knowledge (jñānaśaktim), while breath control (prānayāmaḥ) is the stilling of the mind beyond the gross and subtle levels to attain the supreme pulse (paramam spandanam), withdrawal (prayahāram) is cutting the noose of becoming (bhavapāśanikrntanam), meditation (dhyānam) the reflexive awareness (svasamvedyam) that is the Lord (vibhum), the supporting concentration (dhäranam) is meditation on the supreme self (paramātmānam), and concentration (samādhānam) is placing consciousness equally in all beings. ${ }^{83} \mathrm{I}$ have not come across this kind of

\footnotetext{
79 See Alexis Sanderson (1986, pp. 176-177) and Wallis (2008, pp. 247-295).

${ }^{80}$ Somadeva Vasudeva has written on the six ancillaries of yoga. Concerning those in the Netra-tantra he observes that 'it may actually be more appropriate to compare the eight ancillaries of the Netratantra with the formulaic dhäraṇās taught in the Vijñänabhairava, which show an even greater tendency towards the transcendence of the inherited complex of ritual and yogic procedures' (Vasudeva (2004, p. 382).

81 NT 8.1-6.

82 NT. 8.7-9.

83 NT. 8.10-17.
} 
reinterpretation of yoga elsewhere. The chapter goes on to introduce a number of disparate themes, the self being identical to pure consciousness, and ending by a return to laudation of the netra mantra and its power. In one passage we read:

yadā tu paramāśaktis sarvajñādigunānvitā/āpādādivikāsinyā na vikāmyeti nirmalā //8.31// yāvan na nirmalo hy ātmā baddhạ̣ śaive tad ucyate/yatrasthah puruṣạ̣ sarvam vet[t]y atītam anāgatam //8.32// sanniyamyendriyagrāmam tattattvạ̣ śaktilakṣaṇam/yatra yatra bhaved icchā jñānaṃ vāpi pravartate //8.33// kryāa kṛtyasvarūpā vā tattattvam śaktilakṣaṇam/vyāpakasya sato devi cidrūpasyātmanạ̣ śivāt //8.34// prasaraty adbhutānandā sā śaktih paramā smṛtā/viprasārya tavātmānaṃ sarvajñādigunair guṇi //8.35// sābhāsaḥ kathyate devi śivah paramakāraṇaḥ/ sarvajñah paritṛptaś ca yaś ca bodho hy anādimān //8.36// svatantro hy apraluptaś ca yaś ca vānantaśaktitạ̣/śaktimān guṇabhedena saguṇān vindate guṇi $/ 8.37 / /^{84}$

8.31-32. But when the highest power possessed of all qualities beginning with omniscience, expanding out from foot [to head] is not without desire [?], she is pure. It is said in the Śaiva [scripture] that even though the self is not impure, it is bound. Where the self is established [in its purity] it knows all past and future.

8.33-34ab. One who controls the group of senses, his reality is characterised by power. Wherever knowledge or will arises, there also will be action, whose own nature is to do what is to be done, his reality is characterised by power.

8.34cd-35. O Goddess, for the self whose nature is all-pervading consciousness, wondrous joy proceeds from Śiva. That Power is known as the supreme. Having expanded yourself [in this way, the yogi becomes] endowed with [good] qualities, with the qualities of omniscience and so on.

8.36. Goddess, [this yogi] is called Śiva, shining, the supreme cause, all knowing and completely satisfied, and who is awakened without beginning.

8.37. He is free and not lost, of endless power, the possessor of Power, being the possessor of qualities, he experiences his own qualities by the distinguishing of qualities.

In these verses we see the ideal of the liberated Yogin who moves from a condition of impurity and bondage to a condition of freedom and knowledge, knowing past and future, and, indeed, being omniscient, filled with the power of Siva and identified with his pure consciousness. The Yogin reflects the powers of Śiva, will, knowledge, and action, in himself and becomes Śiva. Such a transformation is to

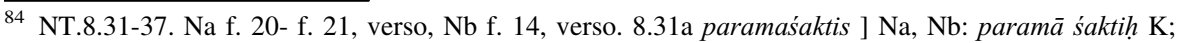
8.31b. sarvajñädi-gunānvitā] $\mathrm{Nb}, \mathrm{K}$ : sarvajñādișu gunānvitā [unmetrical]; 31d: vikāmyeti] $\mathrm{Na}, \mathrm{Nb}$ : vikāsyeta, K. Perhaps we can take vikāmyeti to be vikämyā iti, as an instrumental singular agreeing with vikassinyā, but I have not found this attested elsewhere and the meaning is unclear. The Kashmir text's vikäsyeta, third person singular optative verb, is perhaps an attempt to clarify it. 32a: yāvan] $\mathrm{Na}, \mathrm{Nb}$ : tāvan, K; vetty] Nb, K: vety, Na; 34a: kryākrtya-] Na: kriyākrtya- K, krrtyākrtya- Nb. 34c: sato] Na, Nb: yato, $\mathrm{K} ; 35 \mathrm{c}$ tavātmānam ] $\mathrm{Na}, \mathrm{Nb}$ : tamātmānam $\mathrm{K} ; 36 \mathrm{~b}$ : paramakāraṇah] $\mathrm{Na}, \mathrm{Nb}$ : paramakāraṇam, $\mathrm{K}$. 36d. yaś ca] Na, $\mathrm{Nb}$ : yasya K; -śaktitah ] Na, $\mathrm{Nb}$ : -śaktimah $\mathrm{K}$; 37d: sagunān] $\mathrm{Na}, \mathrm{Nb}$ : svagunān, $\mathrm{K}$.
} 
adopt or absorb the qualities of Śiva, which are good qualities such as omniscience. In this model, the self is gnostic, the Yogin knowing himself to be Siva along with Śiva's powers. Although moral qualities are not explicitly stated, a moral transformation is also implied in the Yogin's becoming the possessor of qualities $(g u n \bar{l})$ and in his control of the senses. But perhaps what is most striking about the passage is that it shares the fundamental structure of the self being filled by forces conceptualised at one level to be outside of it, although the Yogin realises that these powers are in the end, none other than his own. Indeed, the text continues:

8.38. prthagbhedavibhedena nānātvaṃ vicared iha/sarvābhāsa iti prokto nirābhāsas tu kathyate //38// nāham asmi na caivanyo nirābhāso yathā bhavet/sāvasthā paramā proktā śivasya paramātmanạ̣ //39// nāham asmi na cānyo'sti dhyeyaṃ cātra na vidyate/ānandapadasaṃlīnạ̣ jñānaṃ samarasīgatam $/ / 40 / /^{85}$

8.38. He manifests here as variety by splitting into different parts. He is called the manifestation of everything yet is said to be beyond manifestation.

8.39. Beyond manifestation [means] that 'I am not and there is no other.' 86 This state of the supreme self of Siva is called the highest.

8.40. 'I am not and another is not,' here, there is no object of meditation; [the Yogin's] cognition has gone to the sameness of flavour [with Śiva], dissolved in the condition of joy.

The creation of the plurality of the universe is called sarvābhāsa, the manifestation of all, yet it is also nirābhāsa, beyond manifestation, which the text goes on to explain means that this is a condition beyond self and other, which becomes the object of the Yogin's meditation. Here the conception of the self is that it is identical to Siva who is beyond manifestation yet who becomes plural as manifestation. The Netra-tantra is open to Kṣemarāja's non-dualist reading, although in itself it presents an emanationism rather than a pure metaphysical non-dualism. This is a pre-philosophical discourse in which the self is conceptualised as Siva at the highest level: the boundaries of person are extensible beyond individuality. The text goes on to describe meditations in which the Yogin does not focus the mind above or below, with eyes neither shut nor open, focussing on the sense of self as universal. ${ }^{87}$ Having practiced these three methods (the gross, subtle, and supreme) the Yogin becomes a conqueror of death, a practice that is called 'the cheating of time' (kâlasya vañcanam). ${ }^{88}$ This is consonant with the Pratyabhijñā doctrine of the experienced

\footnotetext{
${ }^{85}$ NT 8.38-40. Na f. 21, Nb f. 14, verso. 38b: vicared] Na, Nb: vimriśed, K. 38c: sarvābhāsa] Na, Nb: sa sābhāsa, K. 39a: caivanyo] Na, Nb: cānyo'sti, K. 39b: nirābhāso yathā] Na, Nb: nirābhāsas tadā, K. 40d: jūānam] $\mathrm{Na}, \mathrm{Nb}$ : manah, $\mathrm{K}$.

${ }^{86}$ This would seem to be a stock phrase, attested earlier in the text at 3.14. It is cited by the Śaiva Siddhānta Bhaț̣a Nārāyaṇakaṇtha in his commentary on the Mrgendrāgama, Yogapāda 59, in Abhinavagupta's Tantrāloka 29.64a which adds kevalāh śaktayas tv aham, 'I am merely powers,' and the Tantrasadbhāva 1.328 .

87 NT.8.41-43.

88 NT 8.50 .
} 
self as contracted consciousness realizing its true nature as pure consciousness, the pure subject, who cannot be reduced to a series of cognitions. ${ }^{89}$

\section{Concluding Remarks}

Through developing a typology of persons, I have attempted to explicate implicit anthropologies contained within the Netra-tantra. These form a typology in a hierarchical model of progress reflected in three modes of practice, the gross, the subtle and the supreme meditations. These three conceptualisations of the person the permeable, processual, and gnostic - themselves share an implicit anthropology that person is embedded within a cosmos and furthermore that the soteriological goal of life is to undergo a shift from a condition of permeability in which the person is subjected to externalised forces, through a process of inner development, to a state of liberating gnosis. There is a scale of practice linked to a scale of conceptualisation, from externalised conception of the permeable self, to internalized conception. With permeable boundaries, external powers can enter into the person and change them, usually in a negative way. This is not necessarily linked to moral standing in which moral uprightness is a protection against malevolent forces, but rather to magical protection, or lack of it. But there is some link between ritual impurity and moral laxity as we have seen with Kṣemarāja's commentary on drștipāta where he lists conditions of ritual impurity, such as parturition, alongside moral degradation (see above).

The higher-level practice is the subtle meditation which anticipates an eschatology of empowerment and liberation. Here the hierarchy within the body reflects the hierarchy of the cosmos and we have seen how the symbolic journey through the body in the subtle meditation is a journey through the cosmos to Siva. We saw here that even this subtle meditation contains two systems, the tantraprakriy $\bar{a}$ that envisages an orientation towards verticality and the realization of Siva topically located at the crown of the head, the kulaprakriya moving to a further stage of flooding the body with the nectar of immortality contained there. The person here is filled with the bliss of the Goddess. Lastly, the final and highest meditation is the realization of the person's divinity; the identification with Siva conceptualised as supreme consciousness, through the re-reading of classical Yoga in terms of Śaiva metaphysics. Here the person is innately divine, an understanding brought about through a specific gnosis. Yet these three implicit anthropologies of the permeable, processual, and gnostic self are still contained within the tantric cosmology in which the world of daily transaction is an emanation of higher, more subtle worlds. An emanationist and hierarchical cosmology is the backdrop for these different conceptualisations of the person.

Translating these implicit anthropologies into a different kind of language, we might argue that the eschatological hope of deliverance from affliction, of

\footnotetext{
${ }^{89}$ See Ratié, Le Soi et l'Autre, p. 238: 'La subjectivité (veditrtva) est "quelque chose de plus que les cognitions" (vedanādhika): si toute cognition est le sujet, au sens où elle est une forme contractée de la conscience pure, le sujet, lui, ne se réduit pas à la série des cognitions; il transcende ces formes infiniment variées, mais limitées, de lui-même.'
} 
progressing on an inner journey to God, and of realizing innate divinity, expresses human aspiration particular to the period of the Netra-tantra's popularity. That is, the text articulates an orientation towards verticality and a developmental view of a person as the bearer of capacities for self-enhancement. These anthropologies are esoteric and not really concerned with the person as the bearer of obligations to others and of rights for themselves. While the Netratantra is in some sense a political document in its being used by the Śaiva priest in the courtly domain, its implicit anthropologies are apolitical in presenting models of the person without the explicit specification of gender or caste. The person's spiritual elevation can be achieved through application, through gnosis, and the avoidance of supernatural obstacles to progress. Texts such as this provided the raw material from which philosophy can draw to develop its overt arguments about the nature of person and the ontological status of categories such as self, Lord, and matter.

\section{Compliance with Ethical Standards}

Conflict of interest There is no conflict of interest. I would like to thank the anonymous readers for their helpful comments.

Open Access This article is licensed under a Creative Commons Attribution 4.0 International License, which permits use, sharing, adaptation, distribution and reproduction in any medium or format, as long as you give appropriate credit to the original author(s) and the source, provide a link to the Creative Commons licence, and indicate if changes were made. The images or other third party material in this article are included in the article's Creative Commons licence, unless indicated otherwise in a credit line to the material. If material is not included in the article's Creative Commons licence and your intended use is not permitted by statutory regulation or exceeds the permitted use, you will need to obtain permission directly from the copyright holder. To view a copy of this licence, visit http:// creativecommons.org/licenses/by/4.0/.

\section{References}

\section{Sources}

Amrteśatantra, Na = NAK MS 1-285, NGMPP Reel No. B 25/5. Palm Leaf; Nepalese variant of protoBengali script, 1200 CE (= Nepālīya Saṃvat 320). Nb = NAK 5-4866, NGMPP Reel No. A 171/12. Also see Netra.

İsānaśivagurudevapaddhati (Siddhāntasāra of İsānaśiva), ed. T. Gaṇapati Śāstrī with an introduction by N.P. Unni, 4 vols. Delhi: Bharatiya Vidyā Prakashan, 1988.

Kiraṇatantra. Dominic Goodall, Bhațta Rāmakaṇtha's Commentary on the Kiranatantra vol. 1, chapter 1-6. Pondichéry: Institut Français, 1998.

Kulārṇavatantra, ed. Tārānāth Vidyāratna. Tantrik Texts 5. London: Luzac and Co., 1917. E-text: kulārnavatantram, created from a devanagari electronically typeset file prepared by Dr. Sudhakar Malaviya and then converted to roman transliteration by computer programs created by the Muktabodha Indological Research Institute under the directions of Mark S. G. Dyczkowski. M00031, 2005.

Gheraṇ̣asaṃhitā. James Mallinson. The Gheraṇda Saṃitā: The Original Sanskrit and an English Translation. Woodstock: Yoga Vidya, 2004.

Jayākhya-samhitā. Krishnamacharya Embar (ed.). Baroda: Oriental Institute, 1957.

Tantrāloka of Abhinavagupta with the commentary (-viveka) of Rājānaka Jayaratha. Mukund Rām Śāstrī (ed.) vol.57, Srinagar: KSTS, 1938. E-text: converted from devanagari typesetting files prepared by 
Dr. S. Malaviya by computer programs developed by Muktabodha. The Muktabodha Indological Research Institute under the direction of Mark S. G. Dyczkowski. Catalogue no. M00093, 2007.

Tantrasadbhāva. E-text partially and provisionally edited by Mark S. G. Dyczkowski, 2004, from three manuscripts in the NGMPP.

Netra and Netroddyota: Netratantra with the commentary (-uddyota) by Ksemarāja, edited by Madhusūsan Kaul Śāstrī, vols 1 and 2, KSTS 46, 59. Bombay: Tatva Vivechaka Press,1926,1939. Also see Amrteśatantra.

Parākhya. Dominic Goodall, The Parākhyatantra: A Scripture of the Śaiva Siddhānta, a critical edition and annotated. Pondichéry: Institut Français, 2004.

Paraśurāmakalpasūtra with the commentary (-vrtti) of Rāmeśvara. A. Mahadeva Sastri (ed.). Revised and enlarged by Sakarlal Yajneswar Sastri Dave. Gaekwad Oriental Series 22. Baroda: Oriental Institute, 1979.

Pratyabhijñāhrdaya by Kṣemarāja, edited by J.C. Chatterji KSTS vol 3 (Srinagar: Research Department, Jammu and Kashmir State, 1911).

Mahārthamañjari of Maheśvarānanda with auto-commentary (-parimala). T. Ganapati Sāstrī (ed.). Trivandrum: Trivandrum Sanskrit Series 66, 1919. E-text created by the Muktabodha Indological Research Institute under the direction of Mark S. G. Dyczkowski. M00035, 2006. French translation by Lilian Silburn, La Mahārthamañjari de Maheśvarānanda. Paris: de Boccard, 1968.

Mrgendra. Vidyāpāda and Yogapāda, with the commentary (-vṛtti) of Bhaț̣a Nārāyaṇakaṇțha. Madhusudan Kaul (ed.). Srinagar: KSTS 50, 1930. French translation by Michel Hulin, Mrgendrāgama: sections de la doctrine et du yoga avec la vrtti de Bhațta Nārāyanakanțha et la dipika d'Aghorásivācārya. Pondicherry: Institut Français d'Indololgie, 1980.

Śāradatilaka of Lakșmaṇadeśika with the commentary (-padārthādarśa) of Rāghavabhața, ed. Arthur Avalon. Reprint. Delhi: Motilal Banarsidass, 1982. First published in 1933 as Tantrik Text Series 17, Madras: Ganesh and Co.

Purāṇa, Śiva. (1920). Book 1 (Vidyesvara-Samhita), Gretil version, input by Jun Takashima, 2001. Based on the edition Bombay: Venkatesvara Steam Press, c.

Suprabhedāgama. No editor ascribed. Devakottai: śivāgama siddhānta paripalana sañgham, 1931. E-text: created from a devanagari electronically typeset file, the Muktabodha Indological Research Institute under the direction of Mark S. G. Dyczkowski. Catalogue no. M00090, 2007.

Svacchanda-tantra with the commentary (Svacchandoddyota) of Rājānaka Kṣemarāja. Madhusūdan Kaul Śāstrī (ed.). Srinagar: KSTS vol. 3, 1921.

\section{Secondary Literature}

Bansat-Boudon, L. (2013). 'Introduction.' Lyne Bansat-Boudon and Kamaleshadatta Tripathi. Introduction to tantric philosophy: The Paramārthasāra of Abhinavagupta with the Commentary of Yogarāja. London: Routledge

Bäumer, B. (2019). The yoga of the netra tantra: 'Third eye' and 'overcoming death'. Shimla: Indian Institute of Advanced Study.

Birch, J. (2011). The meaning of hatha in early hathayoga. Journal of the American Oriental Society, 131 (4), 527-554.

Botto, O., et al (eds.). (2004). Du corps humain, au carrefour de plusiers savoirs en Inde. Paris: De Boccard.

Boullier, V., \& Tarabout, G. (Eds.). (2002). Images du corps dans le monde hindou. Paris: CNRS.

Bowker, J. (2015). Why religions matter. Cambridge: Cambridge University Press.

Brunner, H. (1974). Un Tantra du Nord: le Netra Tantra. Bulletin l'École Français d'Extreme Orient, 61, 125-197.

Brunner, H. (1975). Le Sadhaka, personnage oublié de 1'Inde du Sud. Journal Asiatique, 263, 411-443.

Cabezón, J. I. (1998). Scholasticism: Cross-cultural and comparative perspectives. Albany: SUNY Press.

Coakley, S. (Ed.). (1997). Religion and the body. Cambridge: Cambridge University Press.

Feher, M., Naddaff, R., \& Turner, B. S. (Eds.). (1989). Fragments for a history of the human body, zone 3 (Part 1), zone 4 (Part II), and zone 5 (Part III). New York: Urzone Inc. 
Flood, G. (2002). The purification of the body in tantric ritual representation. Indo Iranian Journal, 45, 25-43.

Flood, G. (2011). Body, breath and representation in Śaiva Tantrism. In A. Michaels \& C. Wulf (Eds.), Images of the body in India (pp. 70-83). London: Routledge.

Flood, G. (2013). The truth within: A history of inwardness in Christianity, Hinduism, and Buddhism. Oxford: Oxford University Press.

Frazier, J. (Ed.). (2014). Categorization in Indian philosophy: Thinking inside the box. London: Ashgate.

Freeman, J. R. (1998). Formalized possession among the Tantris and Teyyams of malabar. South Asia Research, 18, 73-98.

Ganeri, J. (2001). Philosophy in classical India. London: Routledge.

Heidegger, M. (1988). The basic problems of phenomenology, trans. Albert Hofstadter. 2nd ed., Bloomington: Indiana University Press.

Jullien, F. (2007). Vital nourishment: Departing from happiness (Nourrir sa vie: à l'écart du Bonheur), trans. Arthur Goldhammer. New York: Zone Books.

Lakof, G., \& Johnson, M. (2003). Metaphors we live by. Chicago: Chicago University Press.

Lewis, I. M., \& Religion, E. (1971). An anthropological study of spirit possession and Shamanism. London: Penguin.

Mallinson, J. (2007). The Khecarīvidyā of Ādinātha: A Critical Edition and Annotated Translation of an Early Text of Hatha Yoga. London: Routledge.

Mallinson, J. (2015). Śāktism and Hațha Yoga. In B. W. Olesen (Ed.), Goddess traditions in tantric Hinduism: History, practice and doctrine (pp. 109-140). London: Routledge.

McClish, M. (2019). Householders, holy and otherwise in the Nīti and Kāma Literature. In P. Olivelle (Ed.), Gṛhastha: The householder in ancient Indian religious culture (pp. 150-170). Oxford: Oxford University Press.

Michaels, A., \& Wulf, C. (Eds.). (2011). Images of the body in India. London: Routledge.

Padoux, A. (1978). Contributions a l'étude du mantraśāstra: I La sélection des mantra (mantrodhāra). Bulletin de l'Ecole français d'Extrême-Orient, 65, 65-85.

Padoux, A. (2002). Corps et Cosmos: L'image du corps du yogin tantrique. In V. Boullier \& G. Tarabout (Eds.), Images du corps dans le monde hindou (pp. 163-187). Paris: CNRS.

Ratié, I. (2011). Le Soi et l'Autre: Identité, difference et altérité dans la philosophie de a Pratyabhijñā. Leiden: Brill.

Sanderson, A. (1985). Purity and power among the Brahmans of Kashmir. In M. Carrithers, S. Collins, \& S. Lukes (Eds.), The category of the person: Anthropology, philosophy, history (pp. 190-216). Cambridge: Cambridge University Press.

Sanderson, A. (1986). 'Mandula and Āgamic Identity in the Trika of Kashmir.' In Mantras et Diagrammes dans l'Hinduism (pp. 176-177). Paris: CNRS.

Sanderson, A. (2004). Religion and the state: Śaiva officiants in the territory of the King's Brahmanical Chaplain. Indo-Iranian Journal, 47, 229-300.

Sanderson, A. (2007). The Śaiva Exegesis of Kashmir. In D. Goodall \& A. Padoux (Eds.), Mélanges Tantriques à la mémoire de Hélène Brunner (pp. 231-582). Pondichéry: Institut Français.

Sanderson, A. (2009). The Śaiva Age. In S. Einoo (Ed.), Genesis and development of Tantrism (pp. 41350). Tokyo: Institute of Oriental Culture.

Sanderson, A. (2012-2013). Śaiva literature. Journal of Indological Studies, nos. 24 and 25, pp. 1-113. Sanderson, A. (2019). How public was Śaivism? In N. Mirnig, M. Rastelli, \& V. Eltschinger (Eds.), Tantric communities in context (pp. 1-48). Vienna: Austrian Academy of Sciences Press.

Shilling, C. (1993). The body and social theory. London: Sage.

Taylor, Charles. (1985). Human agency and language: Philosophical papers, 1. Cambridge: Cambridge University Press.

Törzsök, J. (1999). The Doctrine of magic female spirits: A critical edition of selected chapters of the Siddhayogeśvarimata(tantra) with annotated translation and analysis. D.Phil. thesis, University of Oxford.

Turner, B. S. (1984). The body and society. Oxford: Blackwell.

Vasudeva, S. (2004). The yoga of the Mālinīvijayottaratantra. Pondichery: Institut français d'indologie.

Wallis, C. (2008). The descent of power: Possession, mysticism, and initiation in the Śaiva Theology of Abhinavagupta. Journal of Indian Philosophy, 36, 247-295.

Watson, A. (2006). The self's awareness of itself: Bhațtarāmakanțha's arguments against the buddhist doctrine of no-self. Vienna: de Nobili. 
Wernicke-Olesen, B. (director), Śākta Traditions Website, Oxford Centre for Hindu Studies. http:// saktatraditions.org/netratantra-chapter-7/

Wernicke-Olesen, B., \& Einarsen, S. L. (2018) Übungswissen in Yoga, Tantra und Asketismus. In: Renger, A.-B. \& Stellmacher, A. (Eds.) Übungswissen in Religion und Philosophie: Produktion, Weitergabe, Wandel (pp. 241-257). Berlin: Lit Verlag

White, D. (2012). Netra Tantra at the crossroads of the demonlogical cosmopolis. Journal of Hindu Studies, 5, 145-171.

Publisher's Note Springer Nature remains neutral with regard to jurisdictional claims in published maps and institutional affiliations. 